\title{
Kernos
}

Revue internationale et pluridisciplinaire de religion grecque antique

$20 \mid 2007$

Varia

\section{Zeus’ Missing Ears}

\section{Frederick E. Brenk}

\section{OpenEdition \\ Journals}

\section{Electronic version}

URL: https://journals.openedition.org/kernos/187

DOI: 10.4000/kernos. 187

ISSN: 2034-7871

\section{Publisher}

Centre international d'étude de la religion grecque antique

\section{Printed version}

Date of publication: 1 January 2007

Number of pages: 213-215

ISSN: 0776-3824

\section{Electronic reference}

Frederick E. Brenk, "Zeus' Missing Ears", Kernos [Online], 20 | 2007, Online since 06 September 2011, connection on 08 September 2022. URL: http://journals.openedition.org/kernos/187 ; DOI: https:// doi.org/10.4000/kernos. 187 
Kernos 20 (2007), p. 217-215.

\title{
Zeus' Missing Ears
}

\begin{abstract}
In his treatise On Isis and Osiris, Plutarch tries to explain the meaning of a statue or image $(\dot{\alpha} \gamma \alpha \lambda \mu \alpha)$ of Zeus in Crete, which had no ears. An Egyptian or Egyptianizing image with separate ears, perhaps on a stele, incomprehensible to Greeks, but common in Egypt, might have given rise to Plutarch's bafflement and fantasy interpretation.

Résumé : Dans son traité De Iside et Osiride, Plutarque essaie d'expliquer la signification d'une statue ou d'une image de Zeus $\left(\alpha^{\prime} \gamma \alpha \lambda \mu \alpha\right)$ en Crète, qui n'avait aucune oreille. Une image égyptienne ou "égyptianisante» avec des oreilles séparées, peut-être sur une stèle, incompréhensible aux Grecs mais commune en Égypte, pourrait avoir provoqué la perplexité de Plutarque et son interprétation fantaisiste.
\end{abstract}

At the Plutarch meeting at Rethymnon in Crete, George Patterson and Jane Francis could not find Zeus' missing ears, that is, could not find statues with missing ears in the archaeological record in Crete. ${ }^{1}$ The text they were studying, perhaps significantly, appears in Plutarch's Egyptian treatise, On Isis and Osiris (381e). ${ }^{2} \mathrm{He}$ is talking about the attributes of the Egyptian gods, and since he is noted for thinking in parallels, he turns instinctively to Greek religion. We learn that there was a statue of Zeus on Crete without ears, for which the illuminating explanation he gives is: " . . it is not fitting for the ruler and lord of all to have to listen to anyone."

Significantly, as noted, Plutarch is talking about Egypt at the time. If his comment does have something to do with Egyptian religion, he has arrived at something, which, depending on one's point of view, is exactly the right, or exactly the wrong, conclusion. It is well-known that separate ears often appear on Egyptian or Egyptianizing stelai. Some good examples can be found in the Fitzwilliam Museum, Cambridge, recently published with excellent photos, and in the Ny Carlsberg Museum in Copenhagen. ${ }^{3}$ These "Hearing Ears" were to

\footnotetext{
${ }^{1}$ The Seventh International Congress of the International Plutarch Society, Rethymno University of Crete, Department of Philology, 4-8 May 2005, organized by Professor Anastasios Nikolaidis. I am grateful to Vincent Laisney of the Pontifical Biblical Institute for several helpful suggestions and for some corrections to this article.

2 Thanks to the new E. N. O'NeIL, Plutarch Moralia XVI. Index, Cambridge, Mass., 2004, it is fairly easy now to find references such as the missing ears (under "Zeus").

${ }^{3}$ G.T. MARTin, Stelae from Egypt and Nubia in the Fitzwilliam Museum, Cambridge, c. 3000 BC $A D$ 1150, Cambridge, 2005, p. 102-108, nos. 68-74 with bibliography (all, New Kingdom); M. Jørgensen, Catalogue. Egypt II (1550-1080). Ny Carlsberg Glyptotek, Copenhagen, 1998, "Ear Stelae,” p. 120, \#40, cat. no. 1016, 1017 (18th Dynasty, ca. 1554-1305 B.C.), noting that the ears are meant to entreat the god to respond to prayers.
} 
indicate that the god would listen and respond to the prayers of the petitioner in designated areas of a temple. The presence of three ears indicated plurality, while ten indicated the "all hearing" nature of divinity. ${ }^{4}$ The ears seem to have been especially a mark of personal devotion. ${ }^{5}$ The back of the cella of the Temple of Isis at Pompeii had an aediculum in which stood a statue of Dionysos. Even here, the aediculum frame, within which stood Dionysos (for Osiris probably), was flanked on each side by an ear. Unfortunately, the ears have now vanished. ${ }^{6}$ According to Egyptian belief, such ears were meant to ask the god to listen, and they usually indicate that the stele contains a prayer, something typical of personal piety. Could someone have told Plutarch about a statue with "separate" ears, possible depicted near the statue or image, even outside the frame as at Pompeii? The ears would be particular apt if the statue were one of Zeus Ammon. Possibly, too, it was some ancient Egyptian statue identified as Zeus. At any rate, one could easily jump to the conclusion that Zeus had no ears. Stelai with separate ears are not depicted or listed in the volume published on Crete and Egypt for an exhibition a few years ago, though a remarkable number of Egyptian and Egyptianizing artifacts were found in Crete, many of them extremely ancient. ${ }^{7}$

In a recent article in the American Journal of Archaeology, E. Kyriakidis tries to determine the significance of a number of floating objects on Minoan seals and rings. ${ }^{8}$ (Shades of Plutarch of the Roman and Greek Questions!) Some are the same as Minoan hieroglyphs or pictograms. ${ }^{9}$ Evidently some hieroglyphs were taken over from Egyptian ones. Nine Minoan hieroglyphs are identical to floating objects on the seals. The ear appears on a seal and on three rings, but was neither an Egyptian nor Minoan hieroglyph or pictogram. ${ }^{10}$ On the seal, an eye, like the Egyptian "wedjat" eye, which was one of the Minoan pictograms, is

\footnotetext{
${ }^{4}$ MARTin, o.c. (n. 3), p. 102 to no. 68, citing R. SChlichting, “Ohrenstelen," Lexikon der Ägyptologie IV, cols. 562-566; G. PINCH, Votive Offerings to Hathor, Oxford, 1993, p. 246-264; and W. M. F. Petrie, Memphis I, London, 1909, pls. VIII-XIII, cf. p. 7-8. Add to these, Enka E. Morgan, Untersuchungen zu den Ohrenstelen aus Deir el Medine. Ägypten und Altes Testament 61, Wiesbaden, 2004, esp. p. 55-66, 70-126

${ }^{5}$ Morgan, o.c. (n. 4), p. 55-56.

${ }^{6}$ For the two ears, see N. Blanc, H. ERISTOV, and M. FinCKER, "A Fundamento restituit? Réfections dans le temple d'Isis à Pompéi," RA (2000) 227-310 (p. 242, fig. 10); cf. P. Hoffmann, Der Isis-Tempel in Pompeji, Münster, 1993, p. 64.

A. Karetsou, M. Andreadaki-VlazAKi, et. al. (eds.), Crete-Egypt. Three Thousand Years of Cultural Links, Herakleion and Cairo, 2001.

${ }^{8}$ E. KYriakidis, "Unidentified Floating Objects on Minoan Seals," AJA 109 (2005), p. 137154.

${ }^{9}$ Ibid., p. 148, fig. 16, for a list with the correspondences.

${ }^{10}$ Ibid., p. 141: Isopata ring, Herakeion Museum, no. 424; Archanes ring, Herakleion Museum, no. 989; Zakros sealing, Herakleion Museum, no. 1154; Ashmolean Museum Ring, Ashmolean Museum 1919, no. 56 (p. 145, fig 10a).
} 
depicted free-floating. ${ }^{11}$ In fact, the representation on the seal is similar in concept to Egyptian representations in which the ears or eyes are placed around the image of the divinity depicted. One appears on Stele 08 in Morgan's book on the separate ears. Here the god Thoth, represented as a baboon enthroned in a boat, is flanked by eyes at the level of his head and by two ears at the level of his waist, while another ear is depicted just below the bow of the boat. The ears could be interpreted by a foreign artist as free-floating. ${ }^{12}$ Similar stelai with the god depicted enthroned with separate ears nearby can be found in G.T. Martin's book on the Fitzwilliam stelai, for example, Hathor (Stela no. 69), Sakhmet (no. 70), and Ptah (no. 71).13 In his article on the Minoan flying objects, Kyriakidis concludes that they represented constellations. ${ }^{14}$ There was, then, a long tradition in Cretan art, going back to the Minoans, to portray ears separately. On some of the stelai, the god is represented on the same or another register, with separate ears or pairs of ears nearby. ${ }^{15}$ It would not be too difficult, especially for someone like Plutarch, going on hearsay and evidently speaking of the past ("there was"), to believe that separate ears meant that the god represented by the image had no ears. Of course, through wear and tear the image might have lost its ears, but that would hardly deserve such special mention. Even if totally off track for Egyptian religion, Plutarch came to a brilliant and stunning insight into celestial politics: the head of the divine government (like those of some modern ones?) need not listen to anyone. Our pleas do not fall on deaf ears. There are no ears at all.

Pontifical Biblical Institute

Frederick E. BRENK

Via della Pilotta 25

I - 00187 Rome

E-mail:frederick.brenk@biblico.it

\footnotetext{
${ }^{11}$ These were also employed on Near Eastern seals. See H. PArvine Merrilles, Catalogue of the Western Asiatic Seals in the British Museum. Cylinder Seals VI. Pre-Achaemenid and Achaemenid, London, 2005, pl. XXXV.

${ }^{12}$ Morgan, o.c. (n. 4), p. 86-88 (Cairo, The Egyptian Museum, Inv. No. JE 72025, 19th Dynasty). Stele 10, p. 92-94, depicts the god Haroëris, with a human body and falcon head. Behind the throne are four eyes and two ears.

${ }^{13}$ Fitzwilliam Museum, Acc. Nos. E.54.1935, E.SS.57, E.GA.4356.1943.

${ }^{14}$ KYriakidis, l.c. (n. 8), esp., p. 150-153

${ }^{15}$ E.g. Stele 07, p. 84-85; Stele 08, p. 10, 86-88, 92-94.
} 